\title{
A Guide to Tracking the U.S. Economy
}

Kevin L. Kliesen

\begin{abstract}
Analyzing and forecasting the performance and direction of a large, complex economy like that of the United States is a difficult task. The process involves parsing a great deal of data, understanding key economic relationships, and assessing which events or factors might cause monetary or fiscal policymakers to change policy. One purpose of this article is to reinforce several key principles that are useful for tracking the U.S. economy's performance in real time. Two principles stand out: First, the economy is regularly hit by unexpected economic disturbances (shocks) that policymakers and forecasting models cannot predict. Second, most key data used to measure the economy and track its performance are often revised—and by substantial amounts. (JEL E32, E66)
\end{abstract}

Federal Reserve Bank of St. Louis Review, First Quarter 2014, 96(1), pp. 35-54.

\section{A} nalyzing and forecasting the performance of the U.S. and global economies is a daunting challenge, even for trained, professional economists. This means the challenge facing the nonpractitioner is probably much more difficult. For example, suppose a furniture retailer would like to know the direction of interest rates and the unemployment rate over the next year or two. The direction of interest rates is important because sales of durable goods such as furniture tend to be interest rate sensitive. Likewise, if an increasing percentage of the labor force becomes unemployed, then sales will tend to suffer. But other economic variables are also important. Household wealth, home sales, and consumer sentiment are often used by forecasters and some monetary policymakers to help predict the future path of consumer spending on durable goods.

If the retailer guesses wrong and orders too much or too little furniture from the factory, this may lead to either too much or too little inventory on hand. If too much furniture is ordered, the retailer's costs of carrying the extra inventory would increase, whereas if too little is ordered, the retailer's sales might suffer. In both instances, the retailer's profits would probably be reduced relative to what was expected. In short, a furniture retailer has a powerful incentive to form some assessment of the economy's future performance.

Kevin L. Kliesen is a research officer and economist at the Federal Reserve Bank of St. Louis. Douglas C. Smith and Lowell R. Ricketts provided research assistance.

(c) 2014, The Federal Reserve Bank of St. Louis. The views expressed in this article are those of the author(s) and do not necessarily reflect the views of the Federal Reserve System, the Board of Governors, or the regional Federal Reserve Banks. Articles may be reprinted, reproduced, published, distributed, displayed, and transmitted in their entirety if copyright notice, author name(s), and full citation are included. Abstracts, synopses, and other derivative works may be made only with prior written permission of the Federal Reserve Bank of St. Louis. 
This article is not a how-to exercise in building economic models. Rather, it is intended to assist the noneconomist (nonpractitioner) who wants to analyze and interpret patterns of economic activity at the macro level. A nonpractitioner can be a businessperson, an investor, or any individual interested in monitoring the U.S. economy and/or developing an expectation of its short-term direction. A key conclusion is that the economy's performance can change rapidly. Accordingly, the nonpractitioner seeking some clues about the short-term direction of the economy is advised to monitor a handful of key data and then balance this information against freely available consensus forecasts of the economy over the next six months or so. Over time, consensus forecasts, which are simple averages of a group of professional forecasters, tend to be more accurate than any individual forecast.

\section{A BASIC MODEL OF ECONOMIC FLUCTUATIONS}

A practicing forecaster usually needs a model of how the macroeconomy works. For professional forecasters, the "model" is usually a sophisticated system of equations designed to explain key aspects of the economy — such as growth of real gross domestic product (GDP), inflation, interest rates, stock prices, and the unemployment rate. Nonpractitioners-those not actively managing a large econometric forecasting model-tend to be at a distinct disadvantage in this domain. To compensate, the nonpractitioner who needs to make some judgment about the future direction of the economy should adopt a less formal economic model. Such a model would convey a broad notion of how the economy evolves over the business cycle. One simplistic model the nonpractitioner can use to organize his or her thoughts would be the following: U.S. economic activity—or real GDP—revolves around a trend that grows roughly at a rate determined by the sum of labor productivity growth and population growth. ${ }^{1}$ This trend is sometimes called the growth rate of the economy's potential output. Deviations around this trend-termed "economic fluctuations"-occur because of unexpected disturbances (termed "shocks"), new technologies, and the ever-evolving preferences of consumers, firms, and government policymakers to save, spend, and regulate.

With this simplistic model, the nonpractitioner can make reasonably accurate assessments about the likely direction of the economy over the next several months or quarters. For example, if auto and home sales are strengthening, the unemployment rate is falling, job gains are picking up, and stock prices are rising, then these factors are usually reliable signals that the economy is on an upswing. The nonpractitioner should thus exploit the fact that many key variables move together, which is known as comovement (see the boxed insert on the next page). Comovement is important because the economy's natural state is one of positive growthwhere this growth is dependent on the economy's fundamentals. At any point in time, then, the economy will be growing above or below this trend rate of growth, which will then affect important variables such as, inflation, interest rates, and the unemployment rate. ${ }^{2}$

A model of inflation also differentiates between short- and long-run movements. Inflation can vary over shorter periods of time with changes in energy prices or labor costs. However, over longer periods (several years), actions taken by monetary policymakers will have a significant influence on the economy's inflation rate. Importantly, this transmission stems from 


\section{Exploit the Principle of Comovement}

Private sector professional forecasters and forecasters employed by central banks typically use sophisticated econometric models based on either economic theory or statistical relationships designed to exploit comovements among key variables. The table below depicts one way to measure comovement: by noting correlations among key economic variables. The economic variables listed in the table are real GDP, the unemployment rate, equity prices, the conventional mortgage rate, new orders for manufactured goods, single-family home sales, and consumer price index (CPI) inflation.

\section{Comovement: Cross-Correlation of Four-Quarter Changes or Growth Rates}

\begin{tabular}{|c|c|c|c|c|c|c|c|}
\hline Indicator & Real GDP & $\begin{array}{c}\text { Unemployment } \\
\text { rate }\end{array}$ & $\begin{array}{l}\text { Equity } \\
\text { prices }\end{array}$ & $\begin{array}{c}\text { Conventional } \\
\text { mortgage } \\
\text { rate }\end{array}$ & $\begin{array}{l}\text { New } \\
\text { manufacturing } \\
\text { orders }\end{array}$ & $\begin{array}{l}\text { Single-family } \\
\text { home } \\
\text { sales }\end{array}$ & CPI inflation \\
\hline Real GDP & 1.00 & & & & & & \\
\hline Unemployment rate & -0.78 & 1.00 & & & & & \\
\hline Equity prices & 0.68 & -0.54 & 1.00 & & & & \\
\hline Conventional mortgage rate & 0.46 & -0.33 & 0.18 & 1.00 & & & \\
\hline New manufacturing orders & 0.65 & -0.73 & 0.62 & 0.40 & 1.00 & & \\
\hline Single-family home sales & 0.47 & -0.39 & 0.35 & -0.23 & 0.12 & 1.00 & \\
\hline CPI inflation & 0.34 & -0.50 & 0.16 & 0.31 & 0.58 & -0.03 & 1.00 \\
\hline
\end{tabular}

NOTE: Correlations are based on the sample period 1992:Q3-2013:Q1.

SOURCE: Author's calculations.

The correlations are based on changes over four quarters; the sample period is 1992 to the present. ${ }^{1}$ As an example, the growth of real GDP is highly correlated with the unemployment rate $(-0.78)$, equity prices $(0.68)$, and new manufacturing orders $(0.65)$. These correlations suggest, therefore, that faster real GDP growth tends to be associated with falling unemployment rates, higher stock prices, and faster growth of factory orders. Economists then exploit this comovement over time, as well as economic theory, when building forecasting models or thinking about how the economy evolves in response to changes in some key data.

Economists have also exploited comovement to construct economic indexes designed to measure economic activity using several separate economic series. There are several such indexes designed to mirror broader trends in the economy. Among the more notable are those published by the Federal Reserve Bank of Chicago (Chicago Fed National Activity Index) and the Federal Reserve Bank of Philadelphia (Aruoba-Diebold-Scotti Business Conditions Index). ${ }^{2}$

\footnotetext{
${ }^{1}$ The data are four-quarter growth rates (percent changes), except for the unemployment rate and the conventional mortgage; these are simple changes over four quarters. For example, the unemployment rate in 2013:Q1 was 7.7 percent and in 2012:Q1 was 8.3 percent. Thus, the fourquarter change was 0.6 percentage points.

${ }^{2}$ For the Chicago Fed National Activity Index, see http://www.chicagofed.org/webpages/research/data/cfnai/current_data.cfm. For the AruobaDiebold-Scotti Business Conditions Index, see http://www.phil.frb.org/research-and-data/real-time-center/business-conditions-index/.
} 
the effects of these policy actions on the market's expectations about future inflation. William Poole (2005, pp. 303-04), former president of the Federal Reserve Bank of St. Louis, provided a nice summary of how this might work in practice:

\begin{abstract}
My sense of what I do, which I think is not dissimilar to what most FOMC [Federal Open Market Committee] members do, is attempt to intuit future inflation pressures from current observed pressures as they show up in both price changes and resource pressures, or real gaps, in individual markets. The approach is not totally without theory; for example, wage changes are evaluated in light of expected productivity trends. I attempt to sort out temporary from more lasting wage and price changes and attempt informally to construct an appropriately weighted average of disparate experience in various sectors. I look closely at data on inflation expectations, but treat such data carefully because longer-run expectations are really a vote of confidence on the Fed and not an independent reading on inflation.
\end{abstract}

I am extremely uncomfortable with this approach and believe that it is an invitation to future mistakes. I don't know what better to do.

The nonpractitioner faces another key disadvantage relative to professional forecasters or economic policymakers: resource constraints. Thus, returning to our earlier example, small firms tend to be at a disadvantage compared with large firms in trying to analyze the direction of the economy. Large firms have the resources to hire economists to sift through the data and construct their own sophisticated forecasting models, or they can benefit from professional forecasting services on a contract basis. To help offset this disadvantage, a small business owner will probably adopt some form of naive forecasting ("what happened last year will happen again this year") by reading economic and financial market commentaries from trade associations or perusing "reputable" economic blogs. Some may also use common rules of thumb purported to gauge the strength and direction of the economy, such as the direction of the stock market.

The challenge of economic forecasting extends beyond the technical expertise required to make accurate forecasts. Other factors contributing to this difficult task include the sheer volume of data, persistent data revisions, and correct interpretation of data that may send conflicting signals. Other complications are the responses of monetary and fiscal policymakers and foreign economic developments. Before expounding on how a nonpractitioner might try to overcome these challenges, the next section offers a brief discussion of the events leading up to 2008. The so-called Financial Panic of 2008 and the Great Recession offer several examples of the difficulties both nonpractitioners and professional forecasters face as they attempt to learn about the direction of the economy and forecast its short-term future path.

\title{
THE PERILS OF FORECASTING: A LOOK BACK AT 2008
}

The late economist John Kenneth Galbraith reportedly once remarked that there are two types of forecasters: those who don't know and those who don't know they don't know. Galbraith's aphorism reveals an underappreciated aspect of forecasting: It is inherently difficult. Thus, it was not surprising that the onset of the recent recession was not foreseen by the majority of the professional forecasting community. According to the Business Cycle Dating 


\section{Figure 1}

\section{A Timeline of Blue Chip Forecasts for Real GDP Growth in 2008}

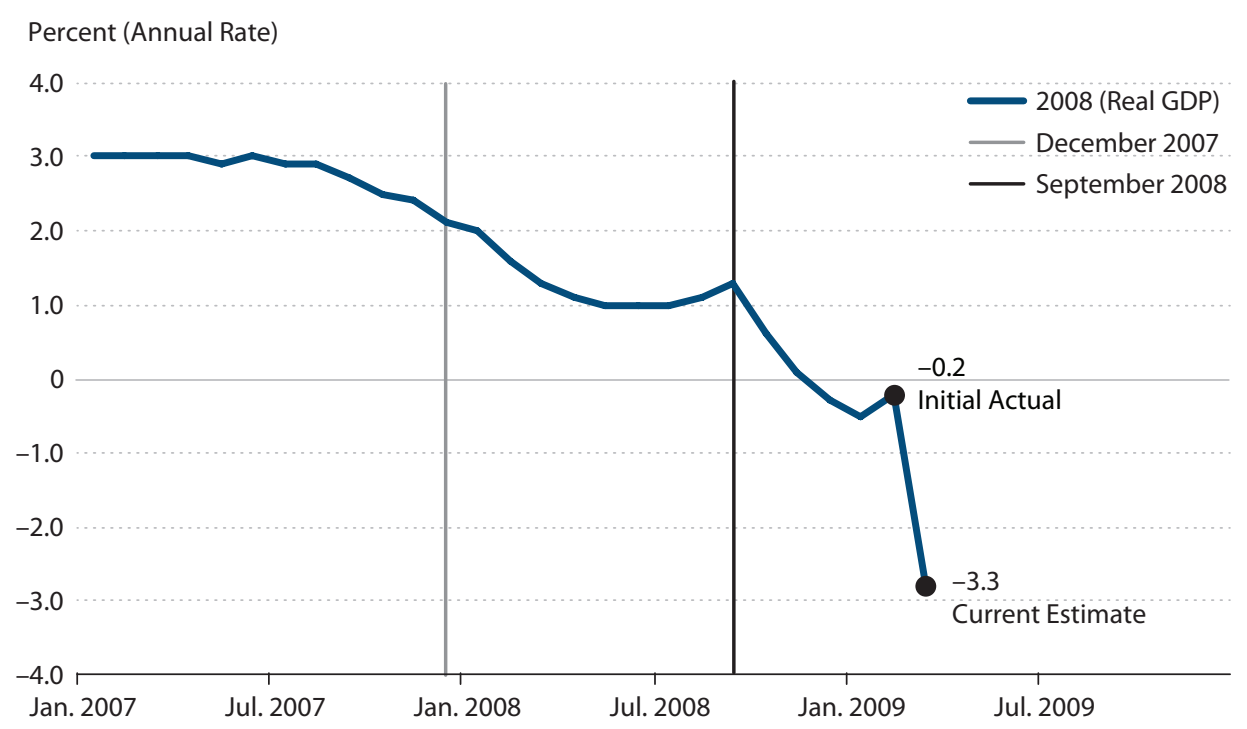

SOURCE: Blue Chip Economic Indicators, various issues.

Committee of the National Bureau of Economic Research (NBER), the U.S. economic expansion that began in November 2001 ended sometime in December 2007. ${ }^{3}$ However, by the end of 2007, very few professional forecasters were predicting a recession in 2008. In fact, in the December 2007 Blue Chip Economic Indicators, the consensus of the Blue Chip forecasters was that real GDP would increase by 2.2 percent in 2008. The average of the 10 most pessimistic forecasters was 1.6 percent, while the average of the 10 most optimistic forecasters was 2.7 percent. $^{4}$

The NBER Business Cycle Dating Committee, like many nonpractitioners, tends to look at real GDP as a key indicator (among other indicators) of the economy's performance. For example, increases (decreases) in expenditures for real final goods and services-such as automobiles, refrigerators, or physician services-are regularly followed by increases (decreases) in employment and a lower (higher) unemployment rate. As Figure 1 shows, throughout most of 2007 the Blue Chip Consensus (BCC) of professional forecasters was that real GDP would increase by about 3 percent in 2008. This figure plots a timeline of BCC forecasts for real GDP growth in 2008. The first forecast was published in January 2007. Beginning in September 2007, though, forecasters began to steadily lower their projections for real GDP growth in 2008. In particular, as discussed below, the forecasts for real GDP growth for 2008 turned sharply lower after the widespread financial turmoil in September 2008. By the end of November 2008, when the NBER announced that the recession began sometime in December 2007, the BCC forecast for real GDP growth in 2008 had dipped slightly below zero. 
Figure 2

\section{A Timeline of Blue Chip Forecasts for CPI Inflation in 2008}

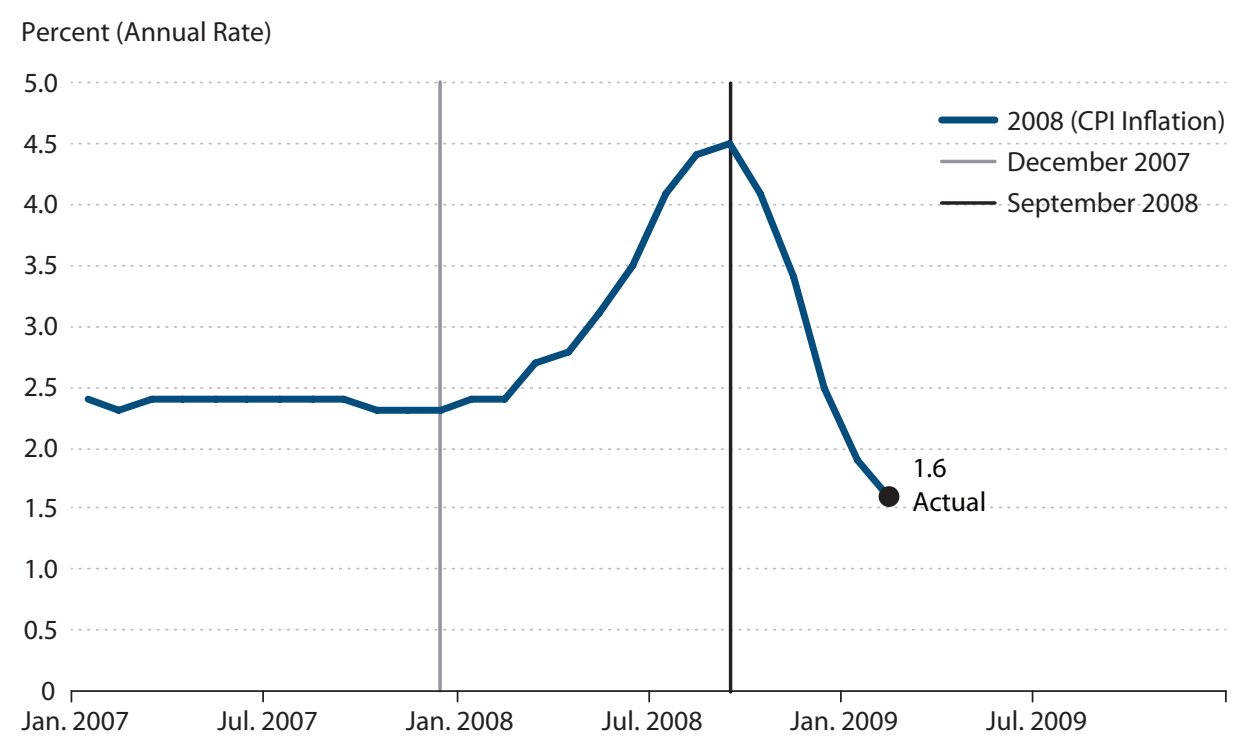

SOURCE: Blue Chip Economic Indicators, various issues.

The direction of inflation is another key indicator of economic performance. First, longterm interest rates such as mortgage rates and corporate bond yields have an inflation premium. ${ }^{5}$ Accordingly, if inflation or the perceived risk of higher inflation in the future increases, then interest rates also usually rise. A higher inflation rate may also spur the Fed to raise its short-term interest rate target, which could also cause long-term rates to rise. ${ }^{6}$ The direction of inflation was markedly different over a good portion of this period. As Figure 2 shows, from January 2007 until March 2008, the BCC forecast was that the CPI would increase by a bit less than 2.5 percent in 2008 .

The relative stability of inflation expectations was somewhat surprising given the behavior of oil prices and actual inflation over this period. From January 2007 to March 2008, crude oil prices rose from about $\$ 55$ per barrel to about $\$ 106$ per barrel. Over the same period, the year-to-year percent change in the CPI rose from 2.1 percent to 4 percent. As oil prices and actual inflation continued to rise over the first half of 2008, forecasters began to dramatically raise their forecasts for inflation in 2008-from about 2.75 percent in April to 4.5 percent in September. ${ }^{7}$ Interestingly, though, forecasts for CPI inflation in 2009 (not shown) rose only slightly, which suggests that most forecasters tended to believe that the upsurge in inflation in 2008 would be temporary. This forecast proved to be accurate. (See the boxed insert on p. 46.)

A key takeaway message from Figures 1 and 2 is that significant, unexpected economic shocks can have important effects on the expectations of forecasters-and thus investors and economic policymakers. The remainder of the article discusses a methodology the nonprac- 


\section{Table 1}

\section{Free Economic Forecasts}

\begin{tabular}{|c|c|c|c|}
\hline Name & Source & Frequency & URL \\
\hline $\begin{array}{l}\text { Survey of Professional } \\
\text { Forecasters }\end{array}$ & $\begin{array}{l}\text { Federal Reserve Bank } \\
\text { of Philadelphia }\end{array}$ & Quarterly & $\begin{array}{l}\text { http://www.phil.frb.org/research-and-data/ } \\
\text { real-time-center/survey-of-professional- } \\
\text { forecasters/ }\end{array}$ \\
\hline $\begin{array}{l}\text { FOMC Summary of } \\
\text { Economic Projections }\end{array}$ & $\begin{array}{l}\text { Federal Open } \\
\text { Market Committee }\end{array}$ & Quarterly & $\begin{array}{l}\text { http://www.federalreserve.gov/monetarypolicy/ } \\
\text { fomccalendars.htm }\end{array}$ \\
\hline $\begin{array}{l}\text { IMF World Economic } \\
\text { Outlook Reports }\end{array}$ & $\begin{array}{l}\text { International } \\
\text { Monetary Fund }\end{array}$ & Semiannually & http://www.imf.org/external/ns/cs.aspx?id=29 \\
\hline NABE Outlook (partial) & $\begin{array}{l}\text { National Association } \\
\text { for Business Economics }\end{array}$ & Quarterly & http://nabe.com/NABE_Outlook_Summary \\
\hline $\begin{array}{l}\text { Budget and Economic } \\
\text { Outlook }\end{array}$ & $\begin{array}{l}\text { Congressional } \\
\text { Budget Office }\end{array}$ & Annually & http://www.cbo.gov/publication/43907 \\
\hline Economic Outlook & OECD & Semiannually & http://www.oecd.org/eco/economicoutlook.htm \\
\hline
\end{tabular}

titioner can use to help analyze the current and short-term performance of the U.S. economy. This approach relies on publicly available data and macroeconomic forecasts. In this framework, "reading the tea leaves" requires an assessment of the following economic conditions:

- the economy's momentum (slowing or accelerating);

- the headwinds or tailwinds affecting this momentum and how long they are expected to last; and

- the risks to the outlook - that is, what could produce growth that is either faster or slower than expected for economic activity and prices.

Endnotes are used for those seeking references or a more in-depth discussion about analyzing general business conditions and the macroeconomy. Although the U.S. economy is obviously affected by events in other countries, the discussion focuses primarily on U.S. data flows and the decisions adopted by U.S. economic policymakers and their potential economic consequences.

\section{KEY PRINCIPLES FOR TRACKING THE ECONOMY}

\section{Principle \# 1: Use Freely Available Forecasts}

The nonpractitioner should adhere to a set of key economic principles. One such principle is comparative advantage. That is, the nonpractitioner should use forecasts developed by professional economists with advanced training and experience in modeling and forecasting. Another principle pertains to the law of demand, which relates the price of a good to its quantity demanded: Free is usually better. Fortunately, reputable forecasts are freely available 


\section{Kliesen}

\section{Figure 3}

\section{Forecasts of Four Key Economic Variables}
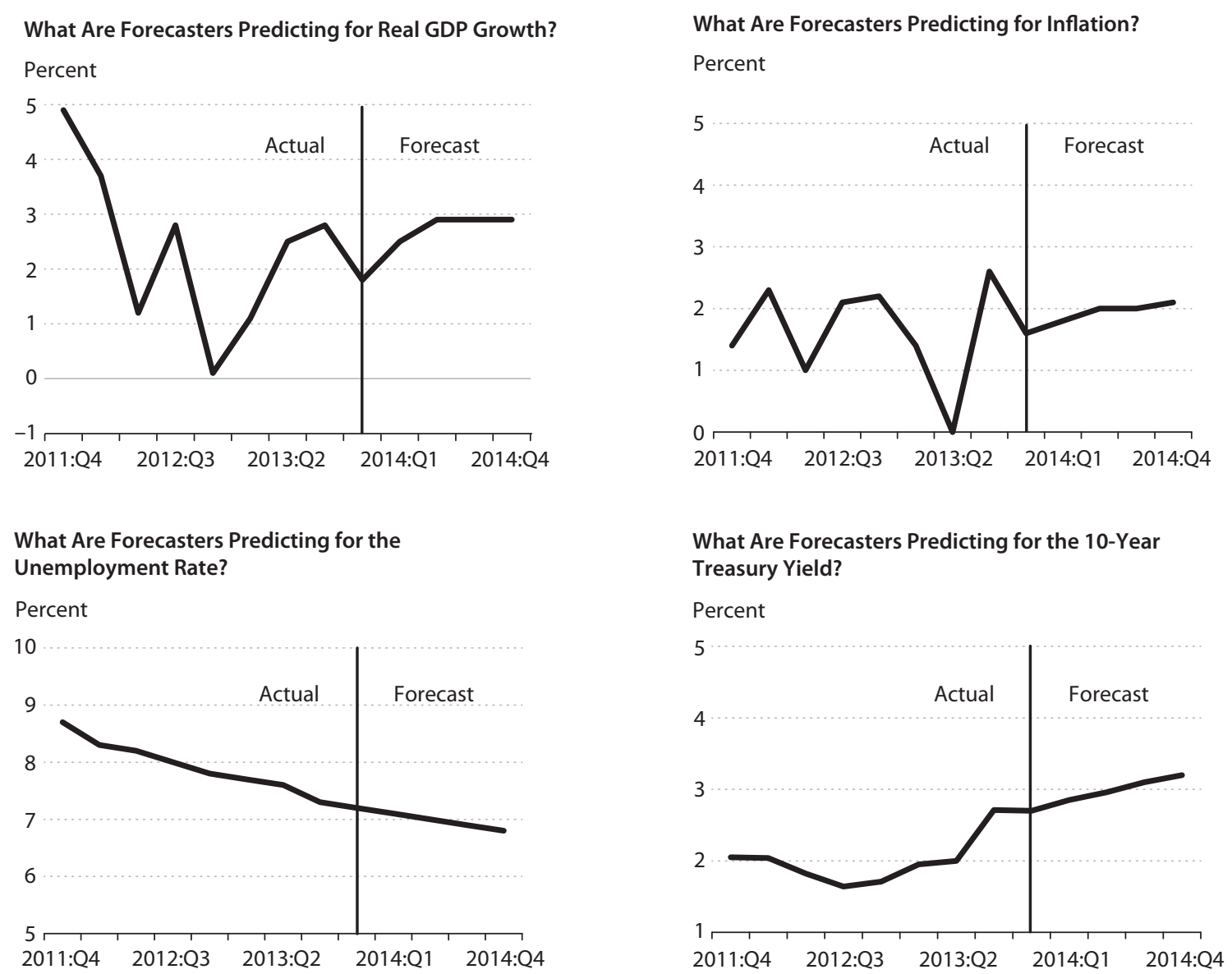

SOURCE: Survey of Professional Forecasters, November 2013.

to the public (Table 1). The law of large numbers is also a related principle: An average, or consensus, of many forecasts is usually better than a single forecast by any one forecaster.

Figure 3 shows forecasts of four key economic variables: real GDP growth, inflation, the unemployment rate, and the 10-year Treasury yield. The forecasts are based on a survey of professional forecasters and published four times per year by the Federal Reserve Bank of Philadelphia in its Survey of Professional Forecasters (SPF). In the November 2013 SPF, the consensus of professional forecasters was that the economy would continue to improve. This was evident by a modest acceleration in real GDP growth, a modest reduction in the unemployment rate, and a modest upswing in long-term interest rates. Forecasters also expected inflation to remain relatively low and stable. 


\section{Principle \#2: Use Forecast Revisions to Gauge Changes in Economic Expectations}

Consensus forecasts are valuable because they provide a "best guess" approach to the economic outlook. This approach differs sharply from relying on a single forecaster whose model or theoretical biases may not be readily known. However, a drawback to consensus forecasts-and, for all practical purposes, all forecasts-is that forecast horizons less than a year or two (four to eight quarters) ahead can change dramatically because of unexpected economic events. Still, the nonpractitioner can use this knowledge to help assess whether the economy is experiencing faster or slower momentum. Just as a car speeds up or slows down, the economy goes through periods when growth of real GDP, inflation, or employment is faster or slower than expected. Before discussing how the nonpractitioner can assess changes in the economy's momentum, it is crucial to acknowledge some key facts about the U.S. economy.

First, the economy's normal state of affairs is one of positive growth in real GDP and in prices (inflation). According to the NBER Business Cycle Dating Committee, from January 1948 to December 2013, the U.S. economy has spent 670 of 792 months (or 85 percent of the time) in expansion. Second, the growth rate of key indicators, such as employment, retail sales, real GDP, and inflation, can vary tremendously from month to month, quarter to quarter, or year to year. Third, actions by the Federal Open Market Committee (FOMC) can influence the economy in important respects, but generally not immediately. Fourth, unexpected disturbances regularly occur that cause forecasts to go awry.

Figures 1 and 2 show how changes in forecasters' expectations are reflected in the economy's momentum. If the economy is exhibiting stable momentum, this generally suggests that the incoming data flows are in line with expectations. In this case, forecasts for real GDP growth (and other key indicators) will remain relatively unchanged, as they were over the first part of 2008. However, faster momentum suggests the incoming data are exceeding expectations (in a good way), and this will be translated into upward revisions in forecasts for real GDP growth. The opposite holds for slower momentum. An example of the latter situation is the downgrading of forecasts for real GDP growth that began in 2008 (see Figure 1). In terms of inflation momentum, Figure 2 shows forecasters continually raised their estimates for CPI inflation for 2008 over the first eight months of the year in response to rising energy prices. Changes in momentum, as reflected in data flows, are important because they help forecasters identify possible shocks to the economy, which can be either positive or negative. These changes thus feed back into revised forecasts.

One drawback to this approach is that freely available forecasts tend to be published at a quarterly or annual frequency (see Table 1). However, identifying momentum changes from the monthly forecasts used in Figures 1 and 2 requires a paid subscription to the Blue Chip Economic Indicators. As an aside, many professional forecasters tend to update their modelbased forecasts on a daily or weekly basis using the latest available data. But a lot can happen in three months, so nonpractitioners who use quarterly forecasts need to augment this framework with something else to identify momentum shifts. One relatively easy method is to systematically track key economic data flows to infer future forecast revisions. 


\section{Principle \#3: Follow the Data to Help Identify Momentum Swings}

Momentum swings during the course of the business cycle can be measured by tracking the evolution of the data relative to the expectations of forecasters and/or financial market participants. These data flows or other economic news may alter the expectations of investors, professional forecasters, and policymakers regarding the strength or weakness of the economy. A recent example of this principle was cited by former Federal Reserve Chairman Ben Bernanke (2013, p. 4) in his press conference following the June 19, 2013, FOMC meeting:

Although the Committee left the pace of purchases unchanged at today's meeting, it has stated that it may vary the pace of purchases as economic conditions evolve. Any such change would reflect the incoming data and their implications for the outlook.

In the context of measuring economic momentum, if key data repeatedly surprise on the upside (downside), then this is a signal that forecasters have been underestimating (overesti-

mating) the strength of the economy. To successfully use this framework, the nonpractitioner must first decide which economic data to focus on. ${ }^{8}$ This step is crucial for two reasons. First, some data are more important than others. And second, some data directly influence forecasts for real GDP and inflation, but most do not. In this section, the discussion focuses on key nonfinancial variables. ${ }^{9}$ The importance of financial market conditions is discussed later.

Table 2 provides a list of key data that the noneconomist should monitor on a regular basis. ${ }^{10}$ In particular, key series released early in the monthly data cycle include

- the manufacturing and nonmanufacturing purchasing managers indexes (PMIs), which provide a broad-based overview of economic activity;

- the nonfarm payroll employment and unemployment rate series published by the Bureau of Labor Statistics in "The Employment Situation"; and

- reports on manufacturing activity (durable goods orders and industrial production), consumer spending (retail sales and auto sales), and housing activity (housing starts and new and existing home sales).

A weekly series-initial claims for unemployment insurance benefits-is also included. Initial claims is an important indicator because (i) it is released each week and (ii) the series tends to have some predictive power for the number of individuals moving into and out of jobs. For example, Kliesen, McCracken, and Zheng (2011) show that job growth tends to weaken or strengthen when the number of initial claims rises above or falls below 400,000. ${ }^{11}$

Table 2 also includes a market-based forecast for each of the indicators released on a recurring basis. For each series, economists and market analysts are surveyed and asked to provide their forecast, or best guess estimate, for the key economic data to be released that week. These market-based expectations for key upcoming data releases are found on many freely available economic calendars. ${ }^{12}$

Table 2 shows how a practitioner can use these expectations to construct a systematic, simple approach to gauge potential changes in economic momentum in real time based on data surprises. This method is depicted in the last three columns of the table. First, for each 
Kliesen

Table 2

A Time Horizon of Key Data Flows (April 2013-May 2013)

\begin{tabular}{|c|c|c|c|c|c|c|c|}
\hline Date & Indicator & Period & $\begin{array}{c}\text { Market } \\
\text { expectations }\end{array}$ & Actual & $\begin{array}{l}\text { Better than } \\
\text { expected? }\end{array}$ & Sign & NTI \\
\hline $3 / 31 / 2013$ & & & & & & 0 & 0 \\
\hline $4 / 1 / 2013$ & ISM Manufacturing PMI & March & 54.2 & 51.3 & No & -1 & -1 \\
\hline $4 / 1 / 2013$ & Construction spending & February & 1.0 & 1.2 & Yes & 1 & 0 \\
\hline $4 / 2 / 2013$ & Factory orders & February & 2.9 & 3.0 & Yes & 1 & 1 \\
\hline $4 / 2 / 2013$ & Total vehicle sales & March & 15.3 & 15.2 & No & -1 & 0 \\
\hline $4 / 3 / 2013$ & ISM Non-Manufacturing PMI & March & 55.8 & 54.4 & No & -1 & -1 \\
\hline $4 / 4 / 2013$ & Initial claims & March 29 & 347 & 385 & No & -1 & -2 \\
\hline $4 / 5 / 2013$ & Total nonfarm payrolls & March & 200 & 88 & No & -1 & -2 \\
\hline $4 / 5 / 2013$ & Private payrolls & March & 209 & 95 & No & -1 & -3 \\
\hline $4 / 5 / 2013$ & Unemployment rate & March & 7.7 & 7.6 & Yes & 1 & -2 \\
\hline $4 / 5 / 2013$ & International trade balance & February & -44.6 & -43.0 & Yes & 1 & -1 \\
\hline $4 / 9 / 2013$ & Wholesale inventories & February & 0.5 & -0.3 & No & -1 & -2 \\
\hline $4 / 10 / 2013$ & Federal budget balance & March & -156.0 & -106.5 & No & -1 & -3 \\
\hline $4 / 11 / 2013$ & Import prices & March & -0.5 & -0.5 & Same & 0 & -3 \\
\hline $4 / 12 / 2013$ & PPI & March & -0.1 & -0.6 & Yes & 1 & -2 \\
\hline $4 / 12 / 2013$ & Core PPI & March & 0.2 & 0.2 & Same & 0 & -2 \\
\hline $4 / 12 / 2013$ & Retail sales & March & 0.0 & -0.4 & No & -1 & -3 \\
\hline $4 / 12 / 2013$ & Retail sales excluding autos & March & 0.1 & -0.4 & No & -1 & -4 \\
\hline $4 / 12 / 2013$ & Business inventories & February & 0.4 & 0.1 & No & -1 & -5 \\
\hline $4 / 16 / 2013$ & Housing starts & March & 0.930 & 1.036 & Yes & 1 & -4 \\
\hline $4 / 16 / 2013$ & Building permits & March & 0.940 & 0.902 & No & -1 & -5 \\
\hline $4 / 16 / 2013$ & CPI & March & 0.0 & -0.2 & Yes & 1 & -4 \\
\hline $4 / 16 / 2013$ & Core CPI & March & 0.2 & 0.1 & Yes & 1 & -3 \\
\hline $4 / 16 / 2013$ & Industrial production & March & 0.2 & 0.4 & Yes & 1 & -2 \\
\hline $4 / 16 / 2013$ & CU rate & March & 78.4 & 78.5 & Yes & 1 & -1 \\
\hline $4 / 18 / 2013$ & Index of Leading Economic Indicators & March & 0.1 & -0.1 & No & -1 & -2 \\
\hline $4 / 22 / 2013$ & Existing home sales (total) & March & 5.010 & 4.920 & No & -1 & -3 \\
\hline $4 / 23 / 2013$ & New home sales & March & 0.420 & 0.417 & No & -1 & -4 \\
\hline $4 / 24 / 2013$ & Durable goods & March & -2.8 & -5.7 & No & -1 & -5 \\
\hline $4 / 24 / 2013$ & Durable goods excluding transportation & March & 0.5 & -1.4 & No & -1 & -6 \\
\hline $4 / 26 / 2013$ & Real GDP & Q1 Advance & 3.0 & 2.5 & No & -1 & -7 \\
\hline $4 / 29 / 2013$ & Personal income & March & 0.4 & 0.2 & No & -1 & -8 \\
\hline $4 / 29 / 2013$ & PCE (expenditures) & March & 0.0 & 0.2 & Yes & 1 & -7 \\
\hline $4 / 29 / 2013$ & Core PCE (prices) & March & 0.1 & 0.0 & Yes & 1 & -6 \\
\hline $4 / 30 / 2013$ & Employment Cost Index & Q1 Advance & 0.5 & 0.3 & Yes & 1 & -5 \\
\hline $5 / 1 / 2013$ & Construction spending & March & 0.7 & -1.7 & No & -1 & -6 \\
\hline $5 / 2 / 2013$ & International trade & March & -42.2 & -38.8 & Yes & 1 & -5 \\
\hline $5 / 2 / 2013$ & Productivity & Q1 Advance & 1.5 & 0.7 & No & -1 & -6 \\
\hline $5 / 2 / 2013$ & Unit labor costs & Q1 Advance & 0.6 & 0.5 & Yes & 1 & -5 \\
\hline $5 / 7 / 2013$ & Consumer credit (\$) & March & 15.0 & 8.0 & No & -1 & -6 \\
\hline $5 / 9 / 2013$ & Initial claims & May 4 & 335 & 323 & Yes & 1 & -5 \\
\hline
\end{tabular}

NOTE: CU, capacity utilization; ISM, Institute for Supply Management; PCE, personal consumption expenditures; PPI, producer price index. SOURCE: Thomson Reuters and author's calculations. 


\section{Assessing Risks to the Economic Outlook}

When economic conditions are perceived as "normal," the risk to the outlook is viewed as balanced. This means that forecasters generally see little reason to alter their assessment of the short-term outlook. However, if there are developments in the domestic or global economy that are judged as "abnormal," then the risks are considered skewed to the upside or downside.

The 2007-09 recession came on the heels of two shocks that have historically proved damaging to the economy's short-term performance: an unexpectedly large increase in crude oil prices and an epic decline in house prices and housing activity. ${ }^{1}$ Oil prices are important because, historically, unexpected increases in oil prices have preceded nearly every post-World War II U.S. recession. Increases in oil prices tend to (i) raise headline inflation rates and (ii) slow the growth of economic activity. Thus, the analyst or investor who concludes that rising oil prices increase the probability of weaker growth and higher inflation is usually on safe terrain. ${ }^{2}$

In a similar vein, housing is important because construction ripples through the economy-for example, affecting sales of consumer durables such as furniture and appliances - and house prices can change household wealth and thus perhaps consumer expenditures (the largest component of GDP). ${ }^{3}$ As this episode demonstrates, nonpractitioners would be wise to pay attention to developments in energy and housing markets to gauge unfolding risks to the outlook. ${ }^{4}$

${ }^{1}$ Stock and Watson (2012) argue that the sharp rise in oil prices and the financial turmoil were key factors that caused the 2007-09 recession.

${ }^{2}$ Hamilton (2008) has documented that 9 of the 10 recessions between 1948 and 2001 were preceded by a rise in oil prices. Rising oil prices also appear to be an important factor explaining business cycles in other advanced economies. See Engemann, Kliesen, and Owyang (2011).

${ }^{3}$ Boldrin et al. (2013) discuss and estimate these housing spillover effects; also see Leamer (2008). Some economists believe that changes in equity prices also have a significant effect on household consumption.

${ }^{4}$ At the same time, many forecasts, including those by the staff members who advise the FOMC, consider numerous alternative scenarios to the so-called baseline forecast. Some forecasts, for example, attach a probability to a recession scenario, but the probability is generally much smaller than the baseline "no recession" scenario.

release, determine whether the data were better than expected. Second, if so, arbitrarily assign an indicator value of +1 ; if not, assign a -1 (worse than expected). If the data met expectations, then assign a value of 0 . Third, sum the indicator values $(+1,-1$, and 0$)$ to obtain a net tracking index (NTI). Using the first indicator in Table 2 (the Institute for Supply Management [ISM] Manufacturing PMI), the market's expectation for March 2013 was 54.2 but the actual estimate was 51.3, which was worse than expected, so we assign a value of -1 . By the end of the list on May 9, the cumulative series-which is the NTI-has a value of -5. A negative value thus indicates that, on net, the data have come in worse than expected and, by assumption, this implies some weaker economic momentum over this period of data flows. Figure 4 plots the NTI for data flows that measure economic activity in the fourth quarter of 2012 and the first quarter of 2013.

Interpreting the NTI is relatively straightforward since it is conditional on one's assumption about the direction of the expected change in economic activity. And since much of the data feed directly into estimates of real GDP or are indicators of economic activity more broadly, the NTI is thus one proxy for the expected change in real GDP in a given quarteractual or forecasted. Though not shown here, the nonpractitioner could also construct an NTI for inflation pressures.

It should be noted that the NTI date listed in Figures $4 \mathrm{~A}$ and $4 \mathrm{~B}$ is not the same as the period of economic measurement. For example, total nonfarm payrolls for March 2013 were released on April 5, 2013. Figure 4A shows that beginning in the second week of December 


\section{Figure 4}

\section{Net Economic Tracking Index}
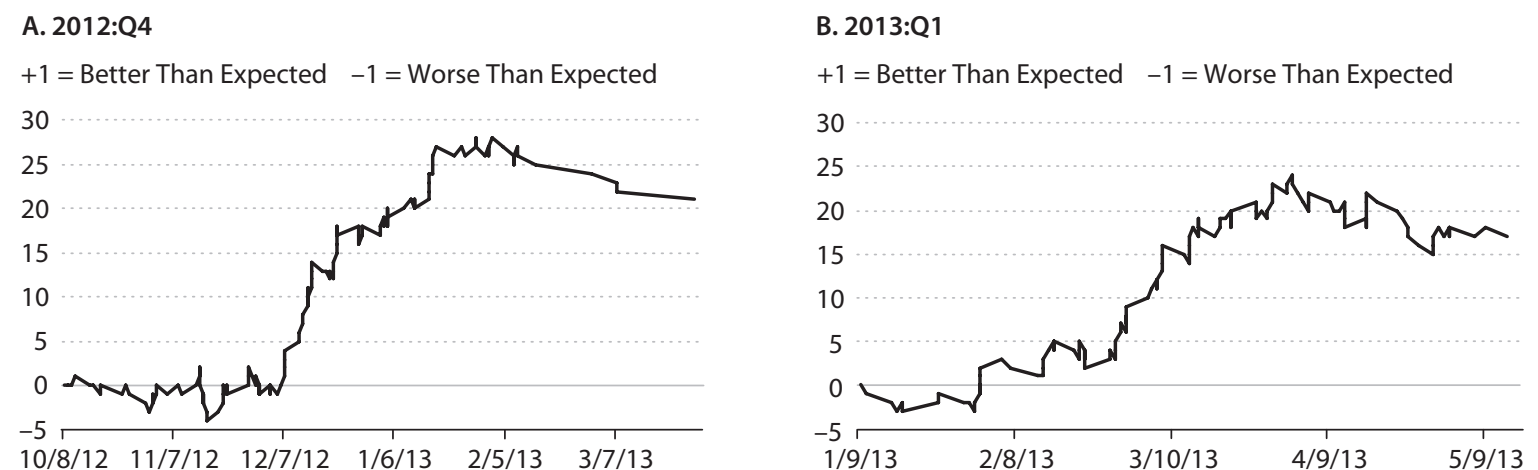

SOURCE: Author's calculations.

2012, the data flows began to be better than expected, on net. All else equal, this was a signal that in the fourth quarter the economy was strengthening by more than expected. However, when the advance estimate was released at the end of January 2013, real GDP for the fourth quarter of 2012 instead was shown to have declined at a 0.1 percent annual rate. This was far below the consensus forecast. Consistent with the NTI, though, subsequent revisions by the BEA slightly raised the advance estimate for real GDP growth in the fourth quarter from -0.1 percent to 0.1 percent.

By contrast, Figure 4B shows that the NTI performed modestly better in the first quarter of 2013. Beginning in late February and early March 2013, the data began to come in consistently better than expected. In response, forecasters began raising their first-quarter estimate for real GDP growth. When the advance estimate was released in late April 2013, the economy was shown to have grown at a 2.5 percent annual rate.

Although the NTI is a very simple metric for measuring momentum, there are a few drawbacks to consider. First, the NTI does not discriminate between the value added of expenditures (e.g., retail sales), employment, survey-based measures, or prices. A second criticism is that the NTI assigns each series the same weight (equal importance). Thus, key data such as payroll employment or housing starts should probably be assigned larger weights than series such as wholesale inventories. One problem confronting all practitioners and nonpractitioners is the inevitability of data revisions. Although the NTI, by design, cannot account for subsequent revisions, it does help minimize this problem because it includes survey data and other types of data that are not revised (e.g., consumer confidence or weekly initial claims). But if the goal is to use the latest data to get a reading on real GDP growth, then revisions are an issue that the nonpractitioner will need to confront. 


\section{Most Key Data Are Based on Sample Estimates}

At any point in time, those interested in reading the economy's tea leaves have a morass of data to follow. The layperson needs to recognize, however, the limitations of many of these data series. For example, most key government statistics reported by the Census Bureau, the Bureau of Economic Analysis (BEA), and other agencies are based on sample-based estimates rather than universe-based counts. For example, to measure the monthly number of jobs created in the United States each month, the Bureau of Labor Statistics (BLS) does not count every new job at every single business and government entity each month. Instead, the BLS surveys approximately 145,000 private nonagricultural businesses and government agencies each month. ${ }^{1}$ These businesses and agencies represent approximately 557,000 individual worksites. This sample-based estimate is then used to construct an estimate of total nonfarm payroll employment for the nation. ${ }^{2}$

Despite what many people may believe, a separate survey is used to estimate the nation's unemployment rate. Each month, the Census Bureau surveys about 60,000 households about their labor force status. These data are then analyzed and published by the BLS in its monthly employment report. In addition to providing an estimate of the unemployment rate, the BLS publishes an estimate of the nation's population, labor force, and the number of people employed, among other metrics. Many other key data series, such as factory orders, housing starts, retail sales, and industrial production, are also based on survey data collected by government and private sector entities. An additional consideration is that most of the key data produced by the government statistical agencies and private sector firms are seasonally adjusted. This is another potential source of measurement error.

${ }^{1}$ These entities employ approximately 9 million nonfarm workers. Technically, the establishment survey counts the number of jobs rather than workers because some people have more than one job.

${ }^{2}$ More detailed information on the methodology used by the BLS to construct labor market measures from the Current Employment Statistics or the Current Population Survey can be found in the BLS Handbook of Methods; see http://www.bls.gov/opub/hom/.

\section{Principle \#4: Beware of Data Revisions}

As noted in the description of Principle 3, revisions to data compound the difficulty of correctly identifying shocks and their significance in real time. These revisions occur largely because much of the source data collected by the U.S. government statistical agencies are based on surveys of a sample of economic entities (firms, households, and government offices and agencies), rather than a survey of the universe of all economic entities. (This process is discussed in the boxed insert above.) As an example of this process, consider the quarterly estimate for the growth of real GDP, which is subject to numerous revisions. These revisions generally reflect updates in the underlying source data or new data based on more complete surveys or income tax records. Sometimes, revisions are made to prices or the underlying statistical methodology used by the government agencies to construct the estimate.

To see how revisions can dramatically change the portrait of the economy's performance, consider the estimate of real GDP growth for the fourth quarter of 2007. According to the NBER, this quarter was the peak of the 2001-07 business expansion. As shown in Figure 5, the BEA released nine estimates of the annual rate of change for real GDP growth in the fourth quarter of 2007. In the advance estimate released in late January 2008, the BEA reported that real GDP rose at a 0.6 percent annual rate. However, when the annual National Income and Product Accounts (NIPA) revision was released in late July 2008, the estimate for real GDP growth in the fourth quarter of 2007 was changed to -0.2 percent. This estimate was subsequently changed to 2.9 percent per year in the 2010 annual NIPA revision but was subsequently marked back down by nearly 1.5 percentage points with the release of the July 2013 NIPA revision. 


\section{Figure 5}

\section{Real-Time Estimates of Real GDP Growth During 2007:Q4}

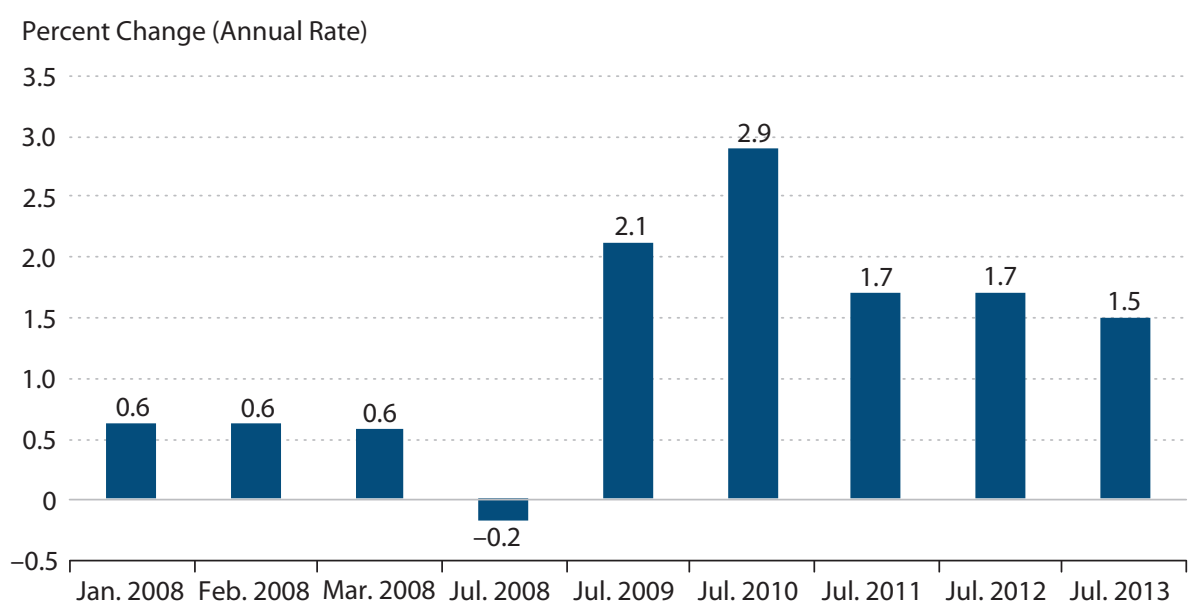

NOTE: Dates reflect the month in which the estimates were published.

SOURCE: Bureau of Economic Analysis and Haver Analytics.

What should the nonpractitioner take away from this discussion? First, the data may not correctly portray the economy's momentum. This possibility suggests that the nonpractitioner should take the monthly data flows and the consensus forecasts with a grain of salt. But what is the alternative? After all, policymakers, FOMC members, businesspersons, and investors have little choice but to react to the incoming data flows. ${ }^{13}$

One way a nonpractitioner can minimize the potential havoc caused by data revisions is to avoid point estimates. Thus, instead of becoming enamored with a forecast for real GDP growth of 3.5 percent (the point estimate), an interest rate of 3 percent, or an unemployment rate of 6.5 percent, the nonpractitioner would attempt to assess whether the economic momentum revealed by forecast revisions and the NTI suggest something more likely on either side of the point estimate. Another method of minimizing the impact of data revisions is to track financial market conditions. Although there is the possibility of a chicken-versus-egg problem since financial markets also react to incoming data flows that are subsequently revised, some financial market series have long been recognized for their leading indicator properties.

\section{Principle \#5: Track Financial Market Conditions ${ }^{14}$}

Economic historians have long known that disturbances in the financial sector can have significant effects on the economy. ${ }^{15}$ Moreover, stabilizing the real economy through its interventions in financial markets is one of the key reasons central banks exist. ${ }^{16}$ The Financial Panic of 2008 provides another example of the financial sector's far-reaching effects on the macroeconomy when asset prices and other key financial market indicators are changing significantly. ${ }^{17}$ Thus, for a more-complete portrait of the economy and potential changes in short- 


\section{Figure 6}

\section{The St. Louis Fed Financial Stress Index}

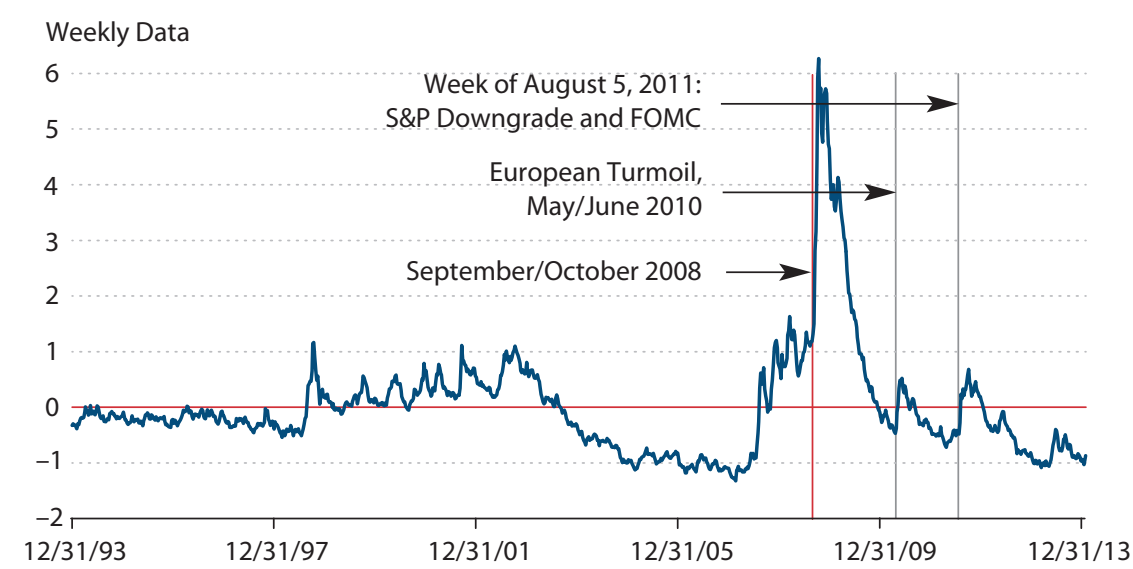

NOTE: The last observation is for the week ending January 31, 2014.

term economic momentum, it is important for the nonpractitioner to understand and track financial market conditions.

One of the key lessons policymakers learned from the 2007-08 experience is an old one: It is extraordinarily difficult to predict financial crises with any degree of confidence. But it can also be difficult to monitor financial conditions because there are literally thousands of different types of financial indicators-ranging from stock price indexes, to interest rates on government and corporate debt, to foreign exchange rates, to more elaborate indicators such as credit default swaps and mortgage-backed securities. ${ }^{18}$ Fortunately, the nonpractitioner can overcome much of this difficulty by focusing on a handful of key indicators. Three come to mind.

The first key financial indicator is a financial stress index (FSI). FSIs are designed to measure changes in financial conditions. For example, when financial market conditions are viewed as stable, then financial stresses tend to be relatively normal. In this situation, lenders are no more risk averse than normal and the volatility of asset prices, such as stock and bond prices, exhibits no unusual movements. By and large, financial market participants have a rather sanguine view of the economy. By contrast, if lenders are becoming more risk averse, asset prices are falling, and volatility is increasing, then financial stresses are on the rise. In this instance, uncertainty about the health of the economy is increasing.

Rising levels of financial stress tend to weaken the real economy through a variety of transmission mechanisms. These include reduced wealth, a reduction in bank lending, and balance-sheet effects that reduce the value of a firm's collateral. The key innovation of FSIs is that they combine different types of financial market indicators into one index-much as the $\mathrm{CPI}$ is one measure of the economy's price level constructed from tens of thousands of different prices on goods and services. For example, economic research has convincingly shown there is significant information content, and thus predictive power, in the U.S. Treasury yield 
curve, commonly calculated as the difference between yields on 10-year Treasury securities and 3-month Treasury bills. The yield curve tends to be upward sloping during times of positive growth in economic activity and tends to narrow as the pace of economic activity slows andimportantly-to invert before recessions. ${ }^{19}$

Another measure of financial market stress is the spread between 10-year Treasury securities and Baa-rated corporate bonds. This interest rate spread, called the credit risk spread, accounts for default risks in private credit markets. Thus, if interest rates are rising and the pace of real GDP growth is slowing, firms tend to experience slowing sales, which adversely affects their revenues and thus their financial condition. In response, the risk associated with lending to firms increases.

One well-known financial stress index that accounts for the information content in these two interest rate spreads is the St. Louis Fed Financial Stress Index (STLFSI). Figure 6 plots the STLFSI and shows that financial market stresses rose sharply prior to several recent economic upheavals that were transmitted to financial markets. These included recent developments in Europe, the downgrade of U.S. sovereign debt by Standard and Poor's, and the unexpected downward revision in U.S. real GDP growth in July 2011 discussed previously. Empirical evidence suggests that rising levels of financial stress are associated with weak or negative growth of industrial production and other measures of economic activity going forward. ${ }^{20}$

\section{CONCLUSION}

Analyzing and forecasting the performance and direction of a large, complex economy like that of the United States is exceptionally difficult. The process involves parsing a great deal of data, understanding key economic relationships, and assessing which events or factors might cause monetary or fiscal policymakers to change policy. One purpose of this article is to reinforce several key principles that a nonpractitioner should use to analyze U.S. economic and financial market conditions. The nonpractitioner can do a reasonably good job of tracking changes in the economy's momentum by taking advantage of freely available macroeconomic forecasts and tracking key data. 


\section{NOTES}

1 Labor productivity is output per hour. Broadly speaking, output is the total value of real GDP. Real GDP measures the inflation-adjusted dollar value of goods and services produced by labor and property located in the United States; these are known as factors of production. A "real" series has been adjusted to remove the effects of changes in prices over time. This adjustment better accounts for increases in the production and consumption of goods and services (i.e., volumes) in response to underlying factors that most affect supply and demand-such as changes in population, productivity, and technological innovations. These real factors are the ones that lead to increases (or decreases) in living standards, what economists term "economic growth." See Gutierrez et al. (2007) for a primer on GDP and its construction.

2 In periods of economic recession, the level of real GDP is declining from one quarter to the next (at a negative growth rate).

3 A rough rule of thumb is that the NBER assumes that the inflection point occurred at the middle of the month.

4 The Blue Chip Consensus is a survey of roughly 50 private sector forecasters. For example, each forecaster submits his or her forecast for real GDP growth and other key macroeconomic and financial variables for the current and upcoming year. The consensus is the simple average (mean) of these forecasts. These forecasts are published in the Blue Chip Economic Indicators on or about the 10th of each month.

5 Economists use the Fisher equation to help analyze changes in interest rates. According to this equation, the nominal interest rate on, for example, a 30-year U.S. Treasury bond is the sum of (i) the real rate of interest earned over this period and (ii) the average inflation rate expected over this period (the inflation premium, a premium demanded by lenders to compensate them for the expected inflation rate over the maturity of the bond). This simple formulation ignores other risk premiums embedded within these nominal interest rates and the complication of selling a security before it matures, which can significantly affect the holding period rate of return on the bond.

6 Many sophisticated forecasting models, including those used by the staff economists at the Board of Governors of the Federal Reserve, assume that the yield on, say, the 10-year Treasury security, is simply an average of a series of 1-year expected future interest rates. Thus, by changing the level of the overnight federal funds rate, the model assumes that the Fed can affect the long-term interest rate.

7 Crude oil prices (measured by West Texas Intermediate) rose from a little more than \$105 per barrel in March 2008 to about $\$ 134$ per barrel in July 2008 (monthly averages). Over the same period, the year-to-year percent change in the CPI increased from 4 percent to 5.6 percent.

8 The St. Louis Fed's FRED (Federal Reserve Economic Data) database contains one of the world's largest collections of freely available economic and financial data. FRED can be accessed at http://research.stlouisfed.org/fred2/.

9 From a GDP-accounting perspective, data that flow directly into real GDP_-such as housing starts, retail sales, and factory shipments - help economists estimate whether the growth of real GDP is likely to change from its previous-quarter estimate. However, other data flows such as employment, initial unemployment claims, inflation, and consumer confidence might also be signals of changes in aggregate demand or supply and thus elicit reactions from policymakers and financial market participants.

${ }^{10}$ All these data, and more, are available on FRED, which currently contains more than 60,000 economic series.

${ }^{11}$ Gavin and Kliesen (2002) provide a description and overview of the initial claims data. They also show that the initial claims indicator has some statistically significant ability to predict monthly changes in payroll employment.

12 Many of these forecasts can be found on the "Calendar of Releases" (http://research.stlouisfed.org/publications/ usfd/cover.pdf) published each week in the St. Louis Fed's U.S. Financial Data publication (http://research.stlouisfed.org/publications/usfd/). Yahoo! provides an economic calendar with market forecasts of these and other variables (http://biz.yahoo.com/c/ec/201315.html).

${ }^{13}$ Orphanides and Van Nordren (2002) have shown that the timeliness of the data and subsequent data revisions make it extremely difficult for monetary policymakers to identify the strength of real GDP relative to potential real GDP (the output gap) in real time.

14 This section draws from Kliesen, Owyang, and Vermann (2012).

${ }^{15}$ See Kindleberger and Aliber (2005) or Reinhart and Rogoff (2009). 
${ }^{16}$ This principle is known as the lender of last resort. Walter Bagehot's Lombard Street (1873) is a classic text on the role of central banks during financial crises.

17 Several other events around this period contributed to the rise of financial market instability. For example, see "The Financial Crisis: A Timeline of Events and Policy Actions" on the St. Louis Fed's website (http://timeline.stlouisfed.org/).

18 Zheng (2012) provides a good summary of key financial indicators (such as the yield curve) for the noneconomist.

${ }^{19}$ See Wheelock and Wohar (2009) for a summary of this research.

${ }^{20}$ See Kliesen, Owyang, and Vermann (2012).

\section{REFERENCES}

Bagehot, Walter. Lombard Street: A Description of the Money Market. London: H.S. King, 1873.

Bernanke, Ben. "Transcript of Chairman Bernanke's Press Conference." June 19, 2013; http://www.federalreserve.gov/mediacenter/files/FOMCpresconf20130619.pdf.

Boldrin, Michele; Garriga, Carlos; Peralta-Alva, Adrian and Sánchez, Juan M. "Reconstructing the Great Recession." Federal Reserve Bank of St. Louis Working Paper 2013-006B, February 2013, revised June 2013; http://research.stlouisfed.org/wp/2013/2013-006.pdf.

Engemann, Kristie M.; Kliesen, Kevin L. and Owyang, Michael T. “Do Oil Shocks Drive Business Cycles? Some U.S. and International Evidence." Macroeconomic Dynamics, November 2011 (Suppl. S3), 15(3), pp. 498-517.

Gavin, William T. and Kliesen, Kevin L. "Unemployment Insurance Claims and Economic Activity." Federal Reserve Bank of St. Louis Review, May/June 2002, 84(3), pp. 15-28; http://research.stlouisfed.org/publications/review/02/05/15-28GavinKliesen.pdf.

Gutierrez, Carlos M.; Glassman, Cynthia A.; Landefeld, J. Steven and Marcuss, Rosemary D. "Measuring the Economy: A Primer on GDP and the National Income and Product Accounts." Bureau of Economic Analysis, September 2007.

Hamilton, James D. "Oil and the Macroeconomy," in Steven N. Durlauf and Lawrence E. Blume (eds.), The New Palgrave Dictionary of Economics. Second Edition. New York: Palgrave Macmillan, 2008.

Kindleberger, Charles P. and Aliber, Robert. Manias, Panics, and Crashes: A History of Financial Crises. Fifth Edition. Hoboken, NJ: John Wiley \& Sons, 2005.

Kliesen, Kevin L.; McCracken, Michael W. and Zheng, Linpeng. “Initial Claims and Employment Growth: Are We at the Threshold?" Federal Reserve Bank of St. Louis Economic Synopses, 2011, No. 41, December 14, 2011; http://research.stlouisfed.org/publications/es/11/ES1141.pdf.

Kliesen, Kevin L.; Owyang, Michael T. and Vermann, E. Katarina. “Disentangling Diverse Measures: A Survey of Financial Stress Indexes." Federal Reserve Bank of St. Louis Review, September/October 2012, 94(5), pp. 369-97; http://research.stlouisfed.org/publications/review/12/09/369-398Kliesen.pdf.

Leamer, Edward E. "Housing Is the Business Cycle," in Housing, Housing Finance, and Monetary Policy. Proceedings of the 2008 Jackson Hole Economic Policy Symposium, Jackson Hole, Wyoming, August 30-September 1, 2007. Kansas City, MO: Federal Reserve Bank of Kansas City, 2008, pp. 149-233; http://www.kansascityfed.org/publicat/sympos/2007/PDF/Leamer_0415.pdf.

Orphanides, Athanasios and Van Norden, Simon. "The Unreliability of Output-Gap Estimates in Real Time." Review of Economics and Statistics, November 2002, 84(4), pp. 569-83.

Poole, William. "Safeguarding Good Policy Practice." Federal Reserve Bank of St. Louis Review, March/April 2005, 87(2, Part 2), pp. 303-06; http://research.stlouisfed.org/publications/review/05/03/part2/PanelDiscussion2.pdf.

Reinhart, Carmen N. and Rogoff, Kenneth S. This Time Is Different: Eight Centuries of Financial Folly. Princeton, NJ: Princeton University Press, 2009.

Stock, James H. and Watson, Mark W. "Disentangling the Channels of the 2007-2009 Recession." Brookings Papers on Economic Activity, Spring 2012, pp. 81-135. 


\section{Kliesen}

Wheelock, David C. and Wohar, Mark E. "Can the Term Spread Predict Output Growth and Recessions? A Survey of the Literature." Federal Reserve Bank of St. Louis Review, September/October 2009, 91(5, Part 1), pp. 419-40; http://research.stlouisfed.org/publications/review/09/09/part1/Wheelock.pdf.

Zheng, Linpeng. "What Do Financial Market Indicators Tell Us?" Federal Reserve Bank of St. Louis Liber8 Economic Information Newsletter. January 2012;

http://research.stlouisfed.org/pageone-economics/uploads/newsletter/2012/Lib0112.pdf. 